significant. These results indicate either that genetic factors operating in a predominantly additive fashion were responsible for the observed strain difference or that balanced dominance was present. The $\mathrm{C} 57$ strain was more active than the JK (Table 1), thus replicating the often-observed negative relationship between activity and defecation in the open-field test. Since the variance of the isogenic generations was greater than that of the $F_{2}$, analysis based on variances was precluded.

Figure 1 presents the results of the aggression test, with data grouped into dichotomous categories of Ss who never fought vs those who fought once or more. The C57 strain had 0\% of fights, while $85 \%$ of the JK males fought at least once out of three opportunities. The .99 confidence interval for the $\mathrm{JK}$ covers the range from .625 to .960 ; a significant difference between the inbred strains is indicated since the $\mathrm{C} 57$ mean is far outside this range.

Partial genetic determination of aggressiveness is indicated from the significant difference between inbred strains. The mode of inheritance is probably not primarily dominance, since the means of the $F_{1}$ and both backcrosses are between the parental values. The high aggressiveness displayed by the segregating $F_{2}$ generation (Fig. 1) may have implications concerning the stimulus variables eliciting aggression. The $F_{2}$ can be expected to show the greatest average variation in segregating heritable characteristics. If increased difference or
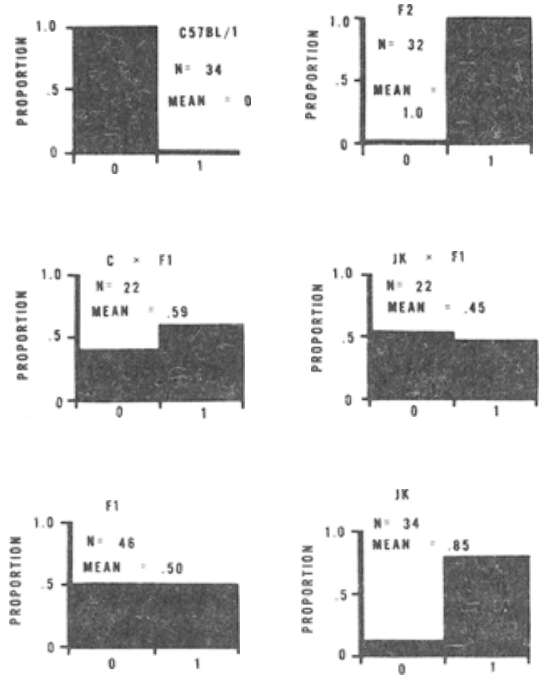

1 FOUEMT ONCE OR WORE

- hever fought

Fig. 1. Proportion of individuals in each genotype who fought in aggression test. strangeness between individuals paired in a match were positively related to the probability of a fight starting, then results similar to those found would be expected. The positive results of Bauer (1956), relating differences to likelihood of aggression, and of Ropartz (1968), implicating the olfactory system in the elicitation and control of aggression, lend support to this possibility.

In the present study, the JK inbred strain was clearly more aggressive, defecated more in the open field, and was less active, than the C57 strain. Therefore, with the present $\mathrm{Ss}$ and rearing regime, there is a strong positive relationship between open-field emotionality and aggressiveness. These results are sufficient to demonstrate that the negative relationship reported elsewhere (Lagerspetz, 1964) is not a necessary relationship and may have been due to accidental factors operating in the selection situation. Aggression and open-field emotionality are definitely not negatively related characters in all mice. REFERENCES

BAUER, F. J. Genetic and experiential factors affecting social reactions in male mice. Journal of Comparative \& Physiological Psychology, 1956, 49, 359-364.

DeFRIES, J. C., \& HEGMANN, J. P. Genetic analysis of open-field behavior. In G. Lindzey and D. D. Thiessen (Eds.), Contributions to behavior-genetic analysis: The mouse as a prototype. New York: Appleton-CenturyCrofts, in press.

KATZENMEYER, C., WHITNEY, G. D., \& NEWELL, T. Estimation of genetic parameters by computer. Behavioral Science, 1969, 14, $160-163$.

LAGERSPETZ, K. Studies on the aggressive behaviour of mice. Helsinki: Suomalainen Tiedeakatemia, 1964.

ROPARTZ, P. The relation between olfactory stimulation and aggressive behavior in mice. Animal Behaviour, 1968, 16, 97-100.

WHITNEY, G. D. The genetics and interrelationships of alcohol preference and various indicants of emotionality in Mus musculus. (Doctoral dissertation, University of Minnesota) Ann Arbor, Mich: University Microfilms, 1967, No. 67-7802.

\section{NOTE}

1. This paper is based on portions of a dissertation submitted in partial fulfillment of the requirements for the $\mathrm{PhD}$ degree, University of Minnesota. Supported in part by NIH Fellowship 4-F1-MH.22, 321-03 Grant MH-11030 to G. Lindzey, and Grant MH-11167 to the Institute for Behavioral Genetics. I thank D. T. Lykken and C. Katzenmeyer for advice and assistance.

\title{
Differences in home-cage-emergence in the rat in relation to infantile handling ${ }^{1}$
}

D. I. WILLIAMS, University of Hull, England, and $P$. A. WELLS, Bedford College, University of London, England

Adult rats, which had either been handled daily between birth and weaning or left undisturbed during this period, were tested on speed of emergence from the home cage. On opening the cage, handled animals reared sooner than did nonhandled ones, and females sooner than males; the additional time taken to raise the nose above the cage top showed sex differences only.

The time taken for an animal to leave a familiar environment is one index of exploration that has been termed, at various times, a measure of wildness/savageness (e.g., Stone, 1932), emotionality (e.g., Billingslea, 1942), shyness (e.g., Hess, 1953), and timidity (e.g., Bindra \& Thompson, 1953). The most familiar environment to the animal is probably the home cage, and measures have been taken simply of the time taken to emerge from it (e.g., Lester, 1967), or of the time taken to come onto a runway (e.g., Bindra \& Thompson, 1953) or into an enclosed alley attached to the cage (e.g., Billingslea, 1942). This relatively simple technique has not produced entirely consistent results.

In an early study, Billingslea (1942) showed that emotional animals, as defined in terms of their behavior in Hall's open-field test, took a greater time to enter a tunnel attached to the cage than did less emotional ones. Later studies, however, with rats (Bindra \& Thompson, 1953; Hunt \& Otis, 1953) and mice (Willingham, 1956) failed to find any relationship between time taken to emerge onto a runway and behavior in the open field. Hunt \& Otis (1963), however, went on to report that emergence from home cage was more sensitive in identifying differences between rats differentially stimulated in infancy 
than was the open-field test. They showed, with male rats, that those "handled" in infancy emerged onto a runway sooner than did "nonhandled" ones, and, in a second experiment, with female rats, that "handled" ones emerged sooner than did "nonhandled" when the cage door was opened. Similarly, Meyers (1965) found that rats "gentled" or receiving "low" electric shock in the immediate postweaning period made more entries into an alley attached to the cage than did "nonhandled" controls; he also reports more entries by females than males. This sex difference is contrary to that found by Lester (1967), who claims that males emerged faster than females. King (1968) also finds sex differences in this situation but gives no indication of their direction. The present study uses the technique of home-cage emergence to examine sex differences and differences produced by infantile stimulation.

\section{SUBJECTS}

Seventy-six black hooded rats, 38 male and 38 female, were used.

\section{HANDLING PROCEDURE}

At birth, complete litters were allocated randomly to one of the two conditions: "handled" (H) or "nonhandled" $(\mathrm{NH})$, but litters that contained fewer than seven animals at weaning were not used.

On each of the 20 days between birth and weaning, the cages of the handled animals were removed singly from the rack and placed on a bench. When the mother had been removed from the cage, the pups were taken individually and at random from the nest and each placed in a separate compartment of the "handling box." This was an open wooden box that contained 12 compartments, each measuring $8.16 \times 8.16 \times 8.16 \mathrm{~cm}$. When all the remaining pups in the litter had been removed, they were then replaced in the same manner. The operation time for each animal was approximately $30 \mathrm{sec}$. Nonhandled animals remained in the normal colony conditions and were undisturbed during this period.

\section{MAINTENANCE}

Maternity cages were of plastic with bedding provided. At 21 days of age, Ss were weaned and placed with litter mates in group cages. At approximately 40 days, they were ear-punched, weighed, and caged with like-sexed litter mates of the same group. Five days prior to the experiment reported here, they were housed individually. The cages were wire mesh drawers, $32 \mathrm{~cm}$ long, $19 \mathrm{~cm}$ wide, and $15 \mathrm{~cm}$ deep, divided in the center by a solid metal divider so as to house two rats individually. All animals were raised and maintained with free access to food and water.

\section{PROCEDURE}

Rats were tested at $102 \pm 4$ days. Previous to this study, they had each been used in a study on maze exploration. The cages were not opened during the 5 days prior to the test, food and water being replenished from outside. Each cage was pulled out a distance of $14 \mathrm{~cm}$, and the time noted, by a separate $O$ for each rat in the pair, for the rat to (1) lift both front paws from the cage floor, and (2) rise up so that the nose was above the level of the top of the cage.

\section{RESULTS}

The mean time to reach Criterion 1 was: for $\mathrm{H}$ females, $3.95 \mathrm{sec}$; for $\mathrm{H}$ males, $15.58 \mathrm{sec}$; for $\mathrm{NH}$ females, $12.66 \mathrm{sec}$; and for NH males, $25.32 \mathrm{sec}$. An analysis of the times to reach this criterion showed a significant effect attributable to handling $(F=59.47, \mathrm{df}=1 / 72, \mathrm{p}<0.001)$ and $\operatorname{sex}$ $(F=103.1, \quad d f=1 / 72, \quad p<0.001)$, and with no significant interaction $(\mathrm{F}<1)$. The same differences are significant if the total times taken to reach the second criterion are measured. If, however, the differences between times to reach Criterion 1 and Criterion 2 are analyzed, only the differences attributable to sex are significant $(F=4.87, \mathrm{df}=1 / 72, \mathrm{p}<0.05)$ the mean differences being: for $\mathrm{H}$ females, $5.4 \mathrm{sec}$; for $\mathrm{H}$ males, $10.0 \mathrm{sec}$; for $\mathrm{NH}$ females, $5.1 \mathrm{sec}$; and for $\mathrm{NH}$ males, $16.5 \mathrm{sec}$

\section{DISCUSSION}

The direction of the sex difference, females rearing before males, is in agreement with that found by Meyers (1965) but opposite to Lester's (1967) finding. There may be strain differences here, but the results of this study do show the expected relationship to sex differences in other exploratory situations, such as mazes (e.g., Hughes, 1968) or the open field (e.g., Broadhurst \& Eysenck, 1964). Similarly, the differences in emergence patterns to the first criterion for $\mathrm{H}$ and $\mathrm{NH}$ animals parallel those found in open-field behavior (e.g., Levine, 1960) and maze studies (e.g., DeNelsky \& Denenberg, 1967).

The fact that the first measure is maximally sensitive to the differences due to infantile stimulation may serve to reconcile some of the previous findings, for those studies (Bindra \& Thompson, 1953; Hunt \& Otis, 1953) that failed to find a correlation between emotionality and emergence time required the animal to emerge onto an open elevated runway, while those that found a correlation (Bilingslea, 1942; Meyers, 1965) used a covered alley, which may have been less stressful. An exception is the study by Hunt \& Otis (1963), who found a relationship between infantile treatment and emergence onto an open elevated runway; but here they express the result not in terms of time to emerge but the degree to which an animal emerged in a given time, and, in fact, only 1 out of 19 "restricted" rats did leave the cage. In such a situation, where the animal is required to enter an unfamiliar and exposed environment, there may be a degree of stress that tends to eliminate some possible behavioral differences. If this is so, then a measure that minimizes stress by recording some aspect of behavior within the familiar home cage will provide an even more sensitive estimate of differences attributable to both sex and early handling.

\section{REFERENCES}

BILLINGSLEA, F. Y. Intercorrelational analysis of certain behavior salients in the rat. Joumal of Comparative Psychology, 1942, 34, 203-211.

BINDRA, D., \& THOMPSON, W. R. Aת evaluation of defecation and locomotion as measures of fearfulness. Journal of Comparative \& Physiological Psychology, $1953,46,43-45$.

BROADHURST, P. L., \& EYSENCK, H. J. Interpretations of exploratory behaviour in the rat. In H. J. Eysenck (Ed.), Experiments in motivation. Oxford: Pergamon Press, 1964. Pp. 375-389.

DeNELSKY, G. Y., \& DENENBERG, V. H. Infantile stimulation and adult exploratory behavior in the rat: Effects of handling upon visual variation seeking. Animal Behaviour, 1967, 15, 568-573.

HESS, E. H. Shyness as a factor influencing hoarding in rats. Journal of Comparative \& Physiological Psychology, 1953, 46, 46.48.

HUGHES, R. W. Behaviour of male and female rats with free choice of two environments. Animal Behaviour, 1968, 16, 92-96.

HUNT, H. F., \& OTIS, L. S. Conditioned and unconditioned emotional defecation in the rat. Journal of Comparative \& Physiological Psychology, 1953, 46, 378-382.

HUNT, H. F., \& OTIS, L. S. Early "experience" and its effects on later behavioral processes in rats: I. Initial experiments. Transactions of the New York Academy of Sciences, 1963, 25, 858-870.

KING, D. L. The consistency of weanling and adult rats. Psychonomic Science, 1968, 13, 29-30.

LESTER, D. Sex differences in exploration of a familiar locale. Psychological Record, 1967, 17, 63-64.

LEVINE, S. Infantile stimulation. Scientific American, 1960, 202, 81-86.

MEYERS, W. J. Effects of different intensities of postweaning shock and handling on the albino rat. Journal of Genetic Psychology, 1965, 106, 51-58.

STONE, C. P. Studies in the dynamics of behavior. Chicago: University of Chicago Press, 1932.

WILLINGHAM, W. W. The organization of emotional behavior in mice. Journal of Comparative \& Physiological Psychology, $1956,49,345-348$.

\section{NOTE}

1. This study was carried out at the University of Hull. We are grateful to Miss Julie Hall and to Mirs. Gillian Bailey for their assistance in conducting the experiment. 